\title{
A gene family in Mycoplasma imitans closely related to the pMGA family of Mycoplasma gallisepticum
}

\author{
Philip F. Markham, Michael F. Duffy, $†$ Michelle D. Glew $\ddagger$ \\ and Glenn F. Browning \\ Author for correspondence: Philip F. Markham. Tel: +6139344 7368. Fax: +61393447374. \\ e-mail : p.markham(à vet.unimelb.edu.au
}

Department of Veterinary Science, The University of Melbourne, Parkville, Victoria, Australia 3052
The avian pathogen Mycoplasma gallisepticum possesses a large gene family encoding lipoproteins which function as haemagglutinins. Representative species of the pneumoniae phylogenetic group of mycoplasmas were examined for the presence of genes homologous to members of this multigene family. Antisera against the PMGA1.1 lipoprotein recognized a $35 \mathrm{kDa}$ protein in Mycoplasma imitans, but did not recognize proteins of Mycoplasma genitalium, Mycoplasma pneumoniae, Mycoplasma pirum, Mycoplasma penetrans or Mycoplasma iowae in Western blots. A fragment of the pMGA1.2 gene and oligonucleotide probes complementary to highly conserved coding and non-coding regions of pMGA genes bound to fragments of genomic DNA of $M$. imitans, but not to the genomes of $M$. genitalium, $M$. pneumoniae, $M$. pirum or $M$. penetrans, and only one probe bound to a fragment of the $M$. iowae genome. One homologue of the pMGA genes was amplified from the $M$. imitans genome by PCR and used as a probe to clone a 3.1 kbp DNA fragment from a library of Hindlll-digested $M$. imitans genomic DNA. The contiguous DNA sequence of the PCR and HindIII clones was predicted to encode one complete and one partial ORF which shared some peptide sequence identity with the pMGA genes, including the signal peptidase II cleavage site and the proline-rich amino-terminal region. Like the pMGA genes, the $M$. imitans genes were found to be members of a large gene family, with an association with GAA trinucleotide repeats, a feature which distinguishes these two families from the homologous v/hA gene family in Mycoplasma synoviae. The identification of these gene families in three phylogenetically distinct avian mycoplasma species, but not in human mycoplasmas, suggests their horizontal transfer between species infecting the same host.

Keywords: pMGA homologue, Mycoplasma imitans, multigene family

\section{INTRODUCTION}

Mycoplasma gallisepticum possesses a large multigene family, with family members encoding a cell-surfaceexposed lipoprotein (pMGA) involved in haemag-

\footnotetext{
†Present address: Walter and Elisa Hall Institute for Medical Research, Parkville, Victoria, Australia 3052

$\ddagger$ Present address: Institute of Bacteriology and Hygiene, Vienna University of Veterinary Medicine, A-1210, Vienna, Josef Baumann-Gasse 1 Austria.
}

The GenBank accession number for the sequence in this paper is AF141940. glutination (Markham et al., 1992, 1994). Analysis of several M. gallisepticum strains revealed that each possessed a repertoire of between 32 and 70 pMGA genes (Baseggio et al., 1996). Several features are highly conserved between pMGA genes, including the presence of the trinucleotide repeat GAA that precedes the transcriptional start of each gene, and the region encoding the leader sequence preceding the aminoterminal cysteine of the mature peptide. It has been suggested that the pMGA gene family in $M$. gallisepticum may be involved in immune evasion and thus aid the continued survival of the organism in the host 
(Markham et al., 1993; Baseggio et al., 1996). Recent studies have also identified a homologous gene family in a phylogenetically distant avian pathogen, Mycoplasma synoviae, although the GAA trinucleotide repeat sequence shown to control pMGA gene transcription in M. gallisepticum (Glew et al., 1998) was not associated with the M. synoviae family (Noormohammadi et al., 1998).

Phylogenetic studies of mycoplasmas using the $16 \mathrm{~S}$ rRNA gene have placed $M$. gallisepticum within the pneumoniae group (Weisburg et al., 1989). This group comprises a number of species including Mycoplasma pneumoniae, Mycoplasma penetrans, Mycoplasma genitalium, Mycoplasma pirum, Mycoplasma iowae, Mycoplasma muris and Ureaplasma urealyticum (Behbahani et al., 1993). The pneumoniae group also contains another avian mycoplasma closely related to M. gallisepticum, both serologically and genetically (Bradbury et al., 1993), and analysis of the 16S rRNA gene sequence of Mycoplasma imitans strain 4229 (ATCC 51306) revealed its closest known neighbour was M. gallisepticum (Boyle \& Morrow, 1994). Recent investigations have shown that cytadherence of $M$. imitans to avian embryo tracheal organ cultures resulted in ciliostasis (Abdul et al., 1996), and that it causes respiratory disease in red-legged partridges (Ganapathy \& Bradbury, 1998) and in turkey poults infected with rhinotracheitis virus (Ganapathy et al., 1996).

Studies of three members of the pneumoniae group ( $M$. pneumoniae, M. genitalium, M. gallisepticum), using hyperimmune sera raised against the P1 attachment protein of $M$. pneumoniae and nucleic acid probes for its gene, identified homologous proteins and genes in both $M$. genitalium and $M$. gallisepticum, suggesting the existence of P1 homologues in these species (Dallo \& Baseman, 1990). The presence of P1-like genes in $M$. gallisepticum and $M$. genitalium has been confirmed with the cloning and sequencing of MGC1 (Keeler et al., 1996; Goh et al., 1998) and MgPa (Inamine et al., 1989), respectively, and a homologue has also been identified in M. pirum (Tham et al., 1994). Each gene encodes a protein with similar structural features to $P 1$.

Considering the importance of pMGA in $M$. gallisepticum it would be of interest to know whether pMGA is found in other members of the pneumoniae group, and if it is, whether the trinucleotide repeat which functions as a transcriptional control motif is also present in other species. The aim of this study was to examine several members of the pneumoniae group, including $M$. imitans, $M$. iowae, $M$. genitalium, $M$. pirum, M. penetrans and M. pneumoniae, for proteins homologous to PMGA and for gene families which may encode them.

\section{METHODS}

Bacterial strains and growth conditions. The media and conditions for growth of strain $\$ 6$ of $M$. gallisepticum have been previously described (Markham et al., 1992). M. imitans
4229 and $M$. iowae serovar J were obtained from C. J. Morrow (origin described by Boyle et al., 1995) and cultured as for M. gallisepticum. M. genitalium (ATCC 33530), $M$. pirum (ATCC 25960), M. penetrans (ATCC 55252) and $M$. pneumoniae strains M129 (ATCC 29342) and P1428 (ATCC 29085) were obtained from the American Type Culture Collection. M. pneumoniae strain FH was a kind gift from V. Peters of the Department of Virology, Royal Children's Hospital, Melbourne. M. genitalium, M. pirum, M. penetrans and $M$. pneumoniae strains were propagated in spiroplasma medium SP4 containing $17 \%$ heat-inactivated foetal bovine serum at $37^{\circ} \mathrm{C}$ with $5 \% \mathrm{CO}_{2} . \mathrm{M}$. pirum was cultured in ATCC medium 243 supplemented with $20 \%$ heat-inactivated horse serum at $37^{\circ} \mathrm{C}$ with $5 \% \mathrm{CO}_{2}$.

Escherichia coli strain DH5 $\alpha$ was used as host for recombinant plasmids as described previously (Markham et al., 1993).

Isolation of mycoplasma DNA. Mycoplasma cells were grown in broth medium until a decrease in $\mathrm{pH}$ of the media had occurred or in the case of $M$. pirum, until an increase in turbidity was observed. Mycoplasma cells were pelleted by centrifugation at $20000 \mathrm{~g}$ for $20 \mathrm{~min}$ at $4{ }^{\circ} \mathrm{C}$ and the cell pellet was resuspended in PBS $(0 \cdot 1 \mathrm{M}$ phosphate, $0.33 \mathrm{M} \mathrm{NaCl}$, $\mathrm{pH} 7 \cdot 4)$. Cells were washed twice more in PBS. The method used for extraction of DNA from $M$. gallisepticum, $M$. imitans and $M$. iowae has been described previously (Kleven et al., 1988). For extraction of DNA from $M$. genitalium, $M$. pirum, $M$. penetrans and $M$. pneumoniae a modification of the method of $\mathrm{Su}$ et al. (1988) was used as overnight incubations for extraction of DNA resulted in degradation of the DNA. Briefly, cell pellets of $M$. genitalium, M. pirum, $M$. penetrans and $M$. pneumoniae were resuspended in $0.5 \%$ SDS, $50 \mathrm{mM}$ EDTA, $50 \mathrm{mM}$ Tris, $\mathrm{pH} 8.0$ ( $\mathrm{HCl})$, to which $50 \mu \mathrm{g}$ proteinase $\mathrm{K} \mathrm{ml}{ }^{1}$ (Boehringer Mannheim) was added and the mixture was incubated at $50^{\circ} \mathrm{C}$ for $2 \mathrm{~h}$. RNase $\mathrm{A}$ (Boehringer Mannheim) was added to give a concentration of $50 \mu \mathrm{g} \mathrm{ml}{ }^{1}$ and the solution was incubated for a further $30 \mathrm{~min}$ at $37^{\circ} \mathrm{C}$. The mixture was extracted sequentially with an equal volume of phenol (ICN Biomedicals) buffered to $\mathrm{pH} 6.7$, twice with an equal volume of $50 \%$ phenol $/ 50 \% 24: 1(\mathrm{v} / \mathrm{v})$ chloroform/isoamyl alcohol and twice with an equal volume of $24: 1(\mathrm{v} / \mathrm{v})$ chloroform/isoamyl alcohol. Following extraction, $3 \mathrm{M}$ sodium acetate $(\mathrm{pH} 7 \cdot 0)$ was added to the mixture to a final concentration of $0 \cdot 2.5 \mathrm{M}$. The DNA was precipitated by adding 2 vols ice-cold ethanol and incubating the solution at $-20^{\circ} \mathrm{C}$ overnight. The DNA was removed by swirling a glass rod through the liquid. The recovered DNA was air-dried and redissolved in $10 \mathrm{mM}$ Tris, $\mathrm{pH} 8.0(\mathrm{HCl})$, $1.0 \mathrm{mM}$ EDTA overnight at $4{ }^{\circ} \mathrm{C}$.

SDS-PAGE and immunoblotting. Mycoplasma cells were grown and harvested as described above. The washed cell pellet was resuspended in $1 \times$ SDS-PAGE lysis buffer $[0.125 \mathrm{M}$ Tris, pH $6.8(\mathrm{HCl}), 4 \%(\mathrm{w} / \mathrm{v})$ SDS, $20 \%$ glycerol, $0.05 \%$ bromophenol blue] and the proteins in a sample were separated by electrophoresis through a $10 \%$ polyacrylamide gel and either stained with Coomassie brilliant blue or transferred onto Immobilon (Millipore) membrane as described previously (Markham et al., 1992). Immunostaining of the membrane was performed essentially as described before (Markham et al., 1992). Briefly, the membrane was incubated in PBS containing $10 \%$ bovine serum albumin $(10 \% \mathrm{BSA} /$ PBS) for $2 \mathrm{~h}$ at room temperature with gentle rocking, then washed three times ( 10 min each) in $0 \cdot 1 \% \mathrm{BSA} / \mathrm{PBS}$ containing $0.05 \%$ Tween 20 . The membrane was incubated for $1 \mathrm{~h}$ at room temperature with polyclonal rabbit antisera raised against pMGA1.1 (Markham et al., 1998) diluted $1 / 500$ in $1 \%$ 
BSA/PBS containing $0.05 \%$ Tween $20(1 \%$ BSA/PBS-T) with gentle rocking, then washed three times as before. The membrane was then incubated for $1 \mathrm{~h}$ at room temperature with swine anti-rabbit horseradish peroxidase conjugate (Dako) diluted $1 / 1000$ in $1 \%$ BSA/PBS-T and then washed three times as before. Conjugate binding was visualized using the chromogen 3,3'-diaminobenzidine (Sigma).

Electrophoresis of digested DNA and Southern blotting. Approximately $2 \mu \mathrm{g}$ mycoplasma DNA was digested to completion with at least $20 \mathrm{U}$ EcoRI (Boehringer Mannheim) or $B g l \mathrm{lI}$ (Boehringer Mannheim) for $2 \mathrm{~h}$ at $37^{\circ} \mathrm{C}$ in the manufacturer's buffer. The fragments of digested DNA were separated by electrophoresis through $0.7 \%$ agarose (Pharmacia) overnight at $1.25 \mathrm{~V} \mathrm{~cm}^{-1}$ and blotted onto Hybond-N + (Amersham) as described previously (Markham et al., 1993). The membrane was incubated at $55^{\circ} \mathrm{C}$ for $4 \mathrm{~h}$ in Church's prehybridization buffer (Church \& Gilbert, 1984), radiolabelled probes were added and hybridized overnight, after which the membrane was washed and autoradiographed using XAR-5 film (Kodak).

DNA probes used in Southern blotting. Radiolabelled probes were prepared from two cloned DNA fragments using $[\alpha-$ $\left.{ }^{32} \mathrm{P}\right] \mathrm{dATP}$ (Amersham) and the Random Primed DNA Labelling kit (Boehringer Mannheim). One of these fragments was a Pst $\mathrm{I}-B g l \mathrm{II}$ DNA fragment $(1.2 \mathrm{kbp})$ containing the aminoterminal region of the pMGA1.2 gene (Markham et al., 1993), and the other a $2 \cdot 1 \mathrm{kbp}$ cloned PCR product from $M$. imitans (this paper). Both radiolabelled probes were hybridized to the membrane at $55^{\circ} \mathrm{C}$ overnight. The membrane probed with the $1.2 \mathrm{kbp}$ fragment was washed three times at $55^{\circ} \mathrm{C}$ in $2 \times \mathrm{SSC}$ $(1 \times \mathrm{SSC}$ is $0.15 \mathrm{M} \mathrm{NaCl}, 0.015 \mathrm{M}$ sodium citrate, $\mathrm{pH} 7 \cdot 4)$, $0.5 \%$ SDS for 5 min each, whilst the membrane probed with the $2.1 \mathrm{kbp}$ fragment was washed three times at $60^{\circ} \mathrm{C}$ in $2 \times$ SSC, $0.5 \%$ SDS for $10 \mathrm{~min}$ each. Two oligonucleotides were used in Southern blotting: Oligo $1\left(5^{\prime}\right.$-GAAGAAGAAGAAGAAGAAGAAGAA-3') and Oligo 2 (5'-ACGAACCAATACCTAATAAACTAACAAA-3') (Baseggio et al., 1996). Each oligonucleotide was $5^{\prime}$-phosphorylated using polynucleotide kinase (Boehringer Mannheim) in the presence of $\left[\gamma_{-}{ }^{32} \mathrm{P}\right]$ ATP (Amersham) and hybridized with the membrane overnight at $50^{\circ} \mathrm{C}$. The membrane was then rinsed twice at room temperature followed by two washes at $50^{\circ} \mathrm{C}$ for $10 \mathrm{~min}$ each in $6 \times \mathrm{SSC} / 0.5 \%$ SDS. The membranes were then autoradiographed using XAR-5 film (Kodak).

PCR, cloning of PCR products and genomic DNA and DNA sequencing. The oligonucleotide T12 (5'-TTTGTTAGTTTATTAGGTATTGGTTCG-3'), corresponding to the conserved DNA sequence of the leader peptide of pMGA family members, and the oligonucleotide C13 (5'-CTTCTTCTTCTTCTTCTTCTТCT $\left.-3^{\prime}\right)$, complementary to the conserved trinucleotide repeat sequence $(\mathrm{GAA})_{n}$ preceding known pMGA genes (Markham et al., 1994), were used as PCR primers. PCR was performed in a $50 \mu \mathrm{l}$ volume of $50 \mathrm{mM} \mathrm{KCl}$, $1.5 \mathrm{mM} \mathrm{MgCl}_{2}, 10 \mathrm{mM}$ Tris $/ \mathrm{HCl}$ ( $\mathrm{pH} 9.0$ at $25^{\circ} \mathrm{C}$ ), with $0.4 \mathrm{mM}$ of each dNTP, $0.4 \mu \mathrm{M}$ of each primer, approximately 5 ng mycoplasma DNA and $1.25 \mathrm{U}$ of the thermostable Taq DNA polymerase (Promega). The PCR was conducted using the Omnigene (Hybaid) thermocycler with an initial incubation at $94^{\circ} \mathrm{C}$ for $120 \mathrm{~s}$ followed by 30 cycles of $50^{\circ} \mathrm{C}$ for $20 \mathrm{~s}, 74^{\circ} \mathrm{C}$ for $90 \mathrm{~s}$ and $94^{\circ} \mathrm{C}$ for $20 \mathrm{~s}$. PCR products from $M$. imitans were separated by electrophoresis in $1.0 \%$ lowmelting-point agarose gel and a band of approximately $2 \mathrm{kbp}$ was excised and purified using the Wizard Prep System (Promega) according to the manufacturer's instructions. Approximately $100 \mathrm{ng}$ of the purified M. imitans PCR product was ligated to the pGEM-T vector (Promega). The ligation mixture was used to transform E. coli DH5 $\alpha$ cells and transformants were screened for the presence of pGEM-T carrying a $2 \mathrm{kbp}$ insert. Plasmid DNA was purified using the QIA filter Plasmid Midi Kit purification system (Qiagen). The nucleotide sequence of the $2 \mathrm{kbp}$ insert was determined by the dideoxy chain-termination method initially using oligonucleotides complementary to the vector and subsequently using oligonucleotide primers complementary to determined nucleotide sequence. A genomic library of HindIII-digested M. imitans genomic DNA in pUC18 was screened using the cloned PCR product radiolabelled with $\left[\alpha^{32} \mathrm{P}\right] \mathrm{dATP}$ (Amersham) as described previously (Markham et al., 1993).

Bioinformatics. The SWISS-PROT and GenBank databases and the genomic databases of $M$. genitalium and $M$. pneumoniae were searched using the BLASTN or BLASTX algorithms (Altschul et al., 1990). Alignment of DNA or protein sequences was carried out using the CLUSTAL $w$ algorithm (Thompson et al., 1994).

\section{RESULTS}

\section{Detection of pMGA gene sequences in $\mathbf{M}$. imitans}

The pMGA gene probe bound to multiple bands in Southern blots of $M$. gallisepticum and M. imitans genomic DNA digested with either EcoRI or BglII (Fig. 1b). The probe did not bind to genomic DNA of $M$. pneumoniae strains FH, M129 or PI1248, M. penetrans, $M$. pirum or $M$. genitalium. Longer exposure (seven times longer than that of Fig. $1 \mathrm{~b}$ ) revealed that up to eight genomic fragments of $M$. imitans and a $1.8 \mathrm{kbp}$ EcoRI fragment of $M$. iowae bound the probe.

The Oligo 1 probe, which was complementary to the GAA repeat sequence associated with pMGA genes in $M$. gallisepticum, bound multiple bands in Southern blots of M. gallisepticum and M. imitans genomic DNA digested with EcoRI or BglII, but did not bind to genomic fragments of $M$. pneumoniae, M. penetrans, $M$. pirum, M. genitalium or $M$. iowae (Fig. 1c). The patterns of hybridizing fragments of $M$. gallisepticum and $M$. imitans DNA were similar with both the pMGA gene and Oligo 1 probes. A third probe, Oligo 2, which was complementary to the highly conserved leader peptide region of pMGA genes, also bound to a similar group of fragments in a Southern blot of EcoRI-digested $M$. gallisepticum genomic DNA and a single $2 \mathrm{kbp}$ fragment of EcoRI-digested M. imitans genomic DNA (results not shown).

\section{Detection of a protein antigenically related to PMGA in $M$. imitans}

Rabbit anti-pMGA antisera reacted with a band of approximately $67 \mathrm{kDa}$ in a Western blot of M. gallisepticum proteins (Fig. 2b, lane 7) and with a single band of approximately $35 \mathrm{kDa}$ in M. imitans (Fig. 2b, lane 1), but not with any proteins of other Mycoplasma species. Monoclonal antibodies mAb66, 71 and 86 (Markham et al., 1992), which are specific for pMGA, did not bind to any protein in Western blots of whole-cell preparations of M. imitans, M. iowae or M. pneumoniae. 
(a)

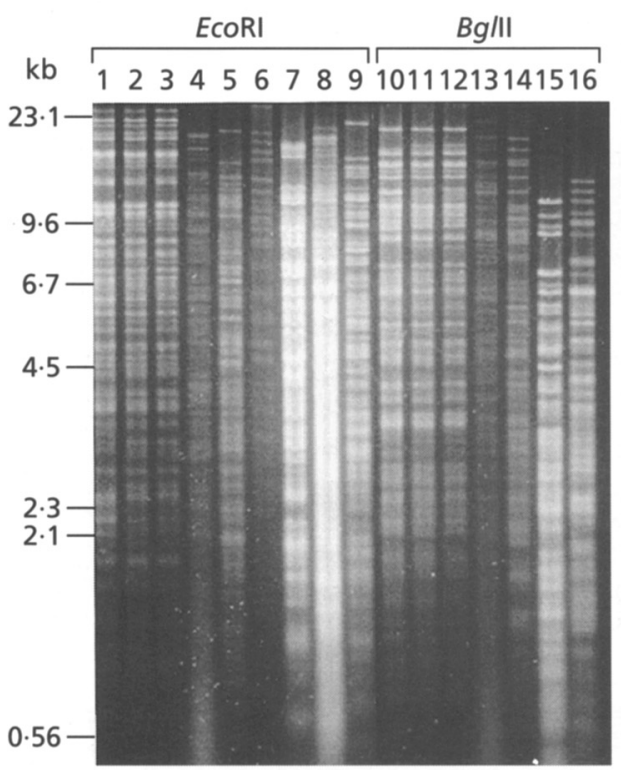

(b)

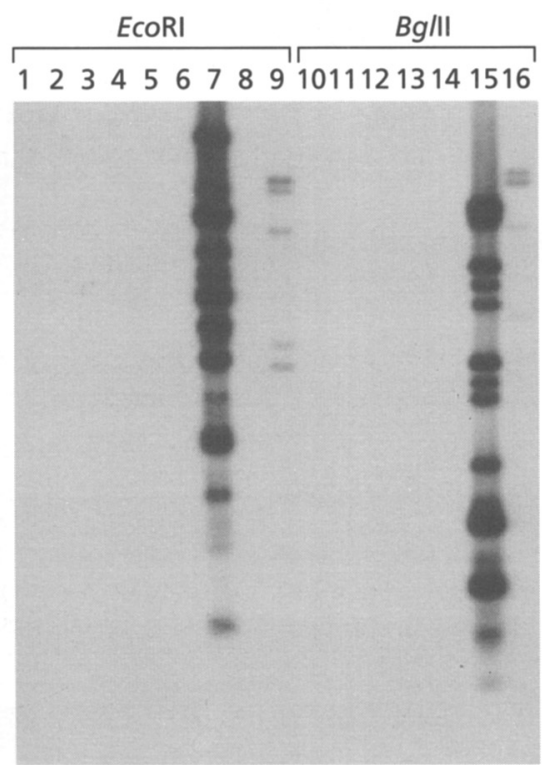

(c)

$$
\text { EcoRI }
$$

12345678910111213141516

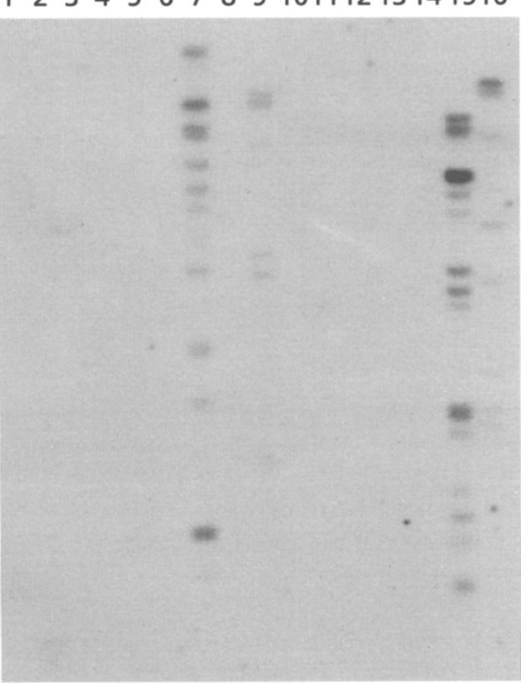

Fig. 1. Restriction endonuclease digestion and Southern blotting of mycoplasma DNA. Mycoplasma genomic DNA was digested with ECORI (lanes 1-9 of each panel) or Bg/ll (lanes 10-16 of each panel). The resultant fragments were separated by electrophoresis, stained with ethidium bromide (a), then Southern blotted and probed with ${ }^{32} \mathrm{p}$ radiolabelled $1.2 \mathrm{~kb}$ Pstl-Bg/II DNA fragment (b) or Oligo 2 (c). The Mycoplasma species were: 1 and 10, M. pneumoniae $\mathrm{FH} ; 2$ and $11, M$. pneumoniae $\mathrm{M} 129 ; 3$ and $12, M$. pneumoniae PI1428; 4 and 13, M. penetrans; $5, M$. pirum; 6 and $14, M$. genitalium; 7 and $15, M$. gallisepticum; $8, M$. iowae; 9 and 16, M. imitans. DNA molecular mass standards were HindIIIdigested lambda phage DNA.

(a)

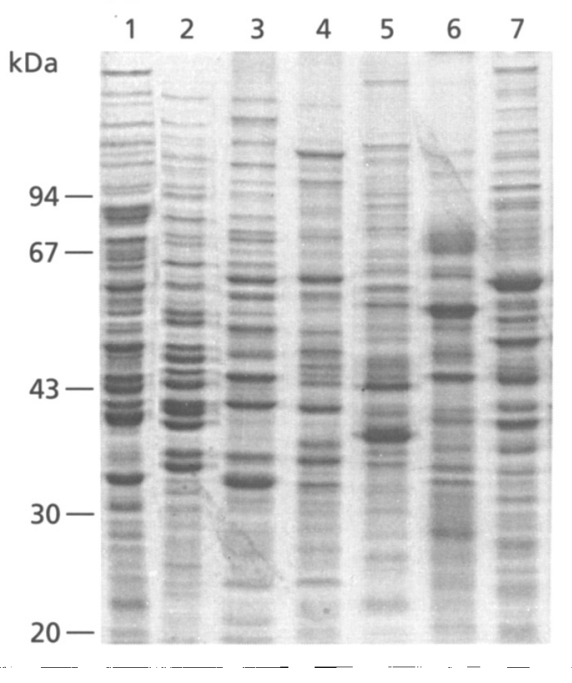

(b)

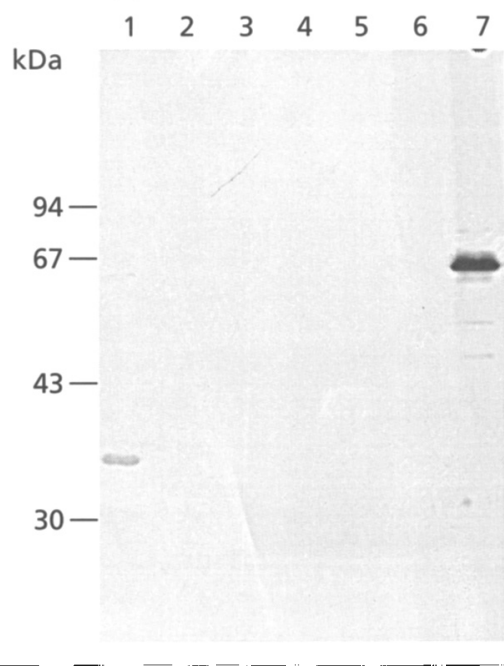

Fig. 2. SDS-PAGE and immunostaining of mycoplasma cell proteins. Mycoplasma whole-cell proteins were separated by SDSPAGE and either stained with Coomassie brilliant blue (a) or Western transferred and probed with rabbit antisera raised against pMGA (b). The species were: 1, M. imitans; 2, M. iowae; $3, M$. pneumoniae $\mathrm{FH} ; 4, M$. genitalium; $5, M$. penetrans; $6, M$. pirum; 7 , $M$. gallisepticum. Molecular mass standards were: phosphorylase $b, 94 \mathrm{kDa} ; \mathrm{BSA}, 67$ $\mathrm{kDa}$; ovalbumin, $43 \mathrm{kDa}$; carbonic anhydrase, $30 \mathrm{kDa}$; trypsin inhibitor, $20 \mathrm{kDa}$ (Pharmacia Biotech).

\section{Cloning and sequencing of a gene from $M$. imitans exhibiting similarity to members of the M. gallisepticum pMGA gene family}

As oligonucleotide probes Oligo 1 and 2 hybridized with $M$. imitans genomic DNA, PCR was conducted using a complementary primer set (T12 and C13). When used in PCR with $M$. gallisepticum genomic DNA as template, these primers are predicted to amplify fragments of approximately $2.2 \mathrm{kbp}$ with some variation in size depending on which pMGA genes were amplified. The architecture of pMGA genes meant that these fragments would contain a truncated pMGA gene which began within the coding sequence for the leader peptide, included the coding sequence for the mature peptide and ended with the GAA trinucleotide repeat of the inter- 


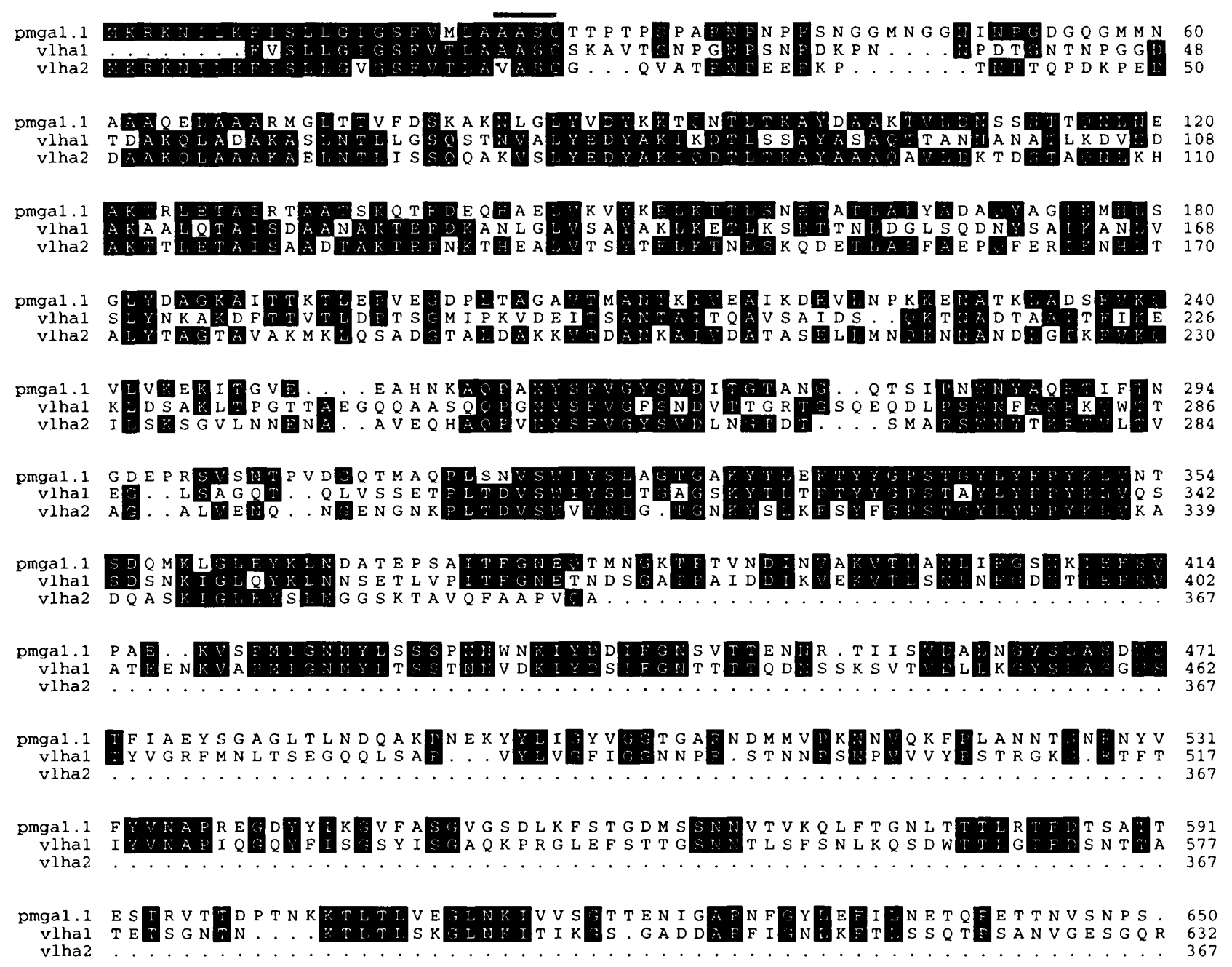

Fig. 3. Alignment of the PMGA1.1 and $M$. imitans VIhA1 and VIhA2 partial amino acid sequences. The three amino acid sequences were aligned and gaps were introduced within the sequence to maximize identity. Identical residues between sequences are shaded black and the signal peptidase II cleavage site is overlined.

genic region preceding the next pMGA gene. Using $M$. imitans genomic DNA as the template in PCR, two major products of $800 \mathrm{bp}$ and $2100 \mathrm{bp}$ were amplified (results not shown), while use of M. gallisepticum DNA as the template resulted in products of $800 \mathrm{bp}$ and $2200 \mathrm{bp}$ (results not shown). No products were detected when M. pneumoniae DNA was used as the PCR template.

The larger PCR product from $M$. imitans was purified from the agarose gel, cloned into the pGEM-T vector (Promega) and subjected to DNA sequencing. The size of the PCR product, including primers, was $2 \cdot 1 \mathrm{kbp}$. The $2 \cdot 1 \mathrm{kbp}$ cloned PCR product was then used to screen a HindIII-digested library of $M$. imitans genomic DNA. The plasmid contained by this isolate contained a $3.1 \mathrm{kbp}$ insert, the sequence of which overlapped the cloned PCR fragment. The two sequences were identical throughout the overlapping region and together covered $3.331 \mathrm{kbp}$ of contiguous sequence containing one com- plete ORF ( $v l h A 1)$ and a second partial ORF terminating at a HindIII cleavage site (vlhA2).

Comparison of both ORFs with SWISS-PROT and GenBank databases revealed that $M$. gallisepticum pMGA DNA and protein sequences had significant identity with the cloned $M$. imitans DNA and both predicted amino acid sequences. The organization of the $M$. imitans genes was similar to that of $M$. gallisepticum pMGA genes, with the GAA trinucleotide repeats commencing 169 nucleotides downstream of the stop codon of the previous gene. Translation of the first ORF, followed by post-translational cleavage of the leader peptide (see below), would yield a mature protein of 616 aa with a molecular mass of $65285 \mathrm{Da}$. The amino acid sequences of pMGA1.1, VlhA1 and VlhA2 were aligned for maximum identity (Fig. 3), producing a consensus sequence showing amino acids in common. The three sequences included the amino acid sequence V/A A S C, which preceded the amino-terminal cysteine and con- 


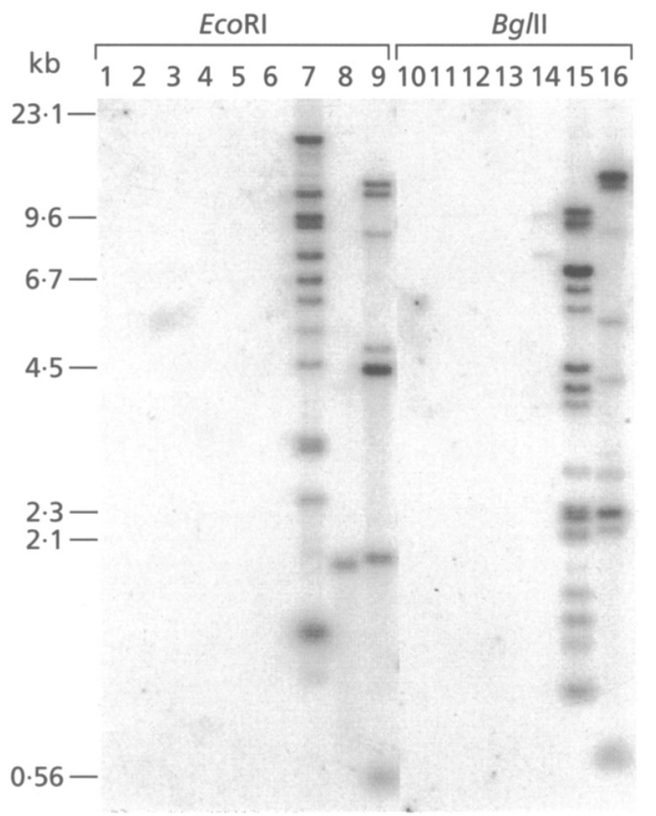

Fig. 4. Southern blot of mycoplasma genomic DNA probed with an $M$. imitans $2.1 \mathrm{kbp}$ DNA fragment. Mycoplasma genomic DNA was digested with EcoRI (lanes 1-9) or Bg/ll (lanes 10-16). The Mycoplasma species were: 1 and 10, M. pneumoniae $\mathrm{FH} ; 2$ and $11, M$. pneumoniae $M 129 ; 3$ and $12, M$. pneumoniae Pl1428; 4 and $13, M$. penetrans; $5, M$. pirum; 6 and $14, M$. genitalium; 7 and $15, M$. gallisepticum; $8, M$. iowae; 9 and 16 , $M$. imitans. DNA molecular mass standards were Hindllldigested lambda phage DNA.

formed to the consensus sequence for cleavage by signal peptidase II, and proline repeat sequences in the aminoterminal region of the mature peptide. Several stretches of amino acid sequence that were shared by all predicted pMGiA polypeptides were also conserved in the $M$. imitans sequence.

\section{The cloned $2.1 \mathrm{kbp}$ PCR product of $\boldsymbol{M}$. imitans DNA contains a member of a gene family}

To verify that the cloned PCR fragment was derived from $M$. imitans genomic DNA the $2 \cdot 1 \mathrm{kbp}$ insert was excised from the pGEM-T vector, radiolabelled with ${ }^{32} \mathrm{P}$ and used to probe a Southern blot of genomic DNA of different Mycoplasma species. The Southern blot was washed under moderately stringent conditions and autoradiographed. The $2.1 \mathrm{kbp}$ probe hybridized most strongly to a $4.5 \mathrm{kbp}$ fragment in EcoRI-digested $M$. imitans DNA and fragments of $13 \mathrm{kbp}$ and $2.3 \mathrm{kbp}$ in BglII-digested M. imitans DNA (Fig. 4, lanes 9 and 16 , respectively) and also bound a $3.3 \mathrm{kbp}$ fragment in HindlII-digested M. imitans DNA (results not shown). A total of $42 \mathrm{kbp}$ of $M$. imitans genomic DNA fragments bound to the $2 \cdot 1 \mathrm{kbp}$ probe and the pattern of fragments bound was identical to that of fragments bound by Oligo 1 and the pMGA DNA fragment.

The $2 \cdot 1 \mathrm{kbp}$ probe also bound the same fragments of $M$. gallisepticum DNA (Fig. 4, lanes 7 and 15) as those bound by the $1.2 \mathrm{kbp}$ pMGA probe and the Oligo 1 probe (Fig. $1 \mathrm{~b}$ and $\mathrm{c}$, respectively). The $2.1 \mathrm{kbp}$ probe also bound a $1.8 \mathrm{kbp}$ EcoRI fragment of $M$. iowae genomic DNA (Fig. 4, lane 8).

There was weak hybridization of the $M$. imitans probe to $M$. genitalium genomic DNA with a fragment of $13 \mathrm{kbp}$ bound in EcoRI digests and fragments of $8.6 \mathrm{kbp}$ and $7 \cdot 2 \mathrm{kbp}$ bound in BgllI digests (Fig. 4, lanes 6 and 14). The $M$. genitalium database was searched for similarity with the $2.1 \mathrm{kbp}$ sequence using the BLAST search algorithm (Altschul et al., 1990) and several sequences were detected with varying levels of DNA identity. The segment of the $M$. genitalium genome (U39715) which had the highest similarity scores contained a GAA repeat trinucleotide and would yield EcoRI and BgllI fragments of $13 \mathrm{kbp}$ and $8 \mathrm{kbp}$, respectively, similar in size to the observed weakly hybridizing fragments. However this region did not contain an ORF homologous to the pMGA genes.

\section{Conservation of 5 non-coding regions on either side of the transcriptional control motif}

Alignment of the $5^{\prime}$ non-coding region of all characterized pMGA genes and of the $v / h A 2$ gene characterized in this study revealed considerable conservation of sequences between the GAA repeat motif known to control transcription of pMGA genes and the GTG start codon (Fig. 5). There were several regions of very high sequence conservation across all genes, notably at the - 10 region (GAAAAT), at the transcriptional start point and the seven bases $3^{\prime}$ to it (GATTTATT), and just $5^{\prime}$ to the GTG start codon (TTTAA). In addition there were several highly conserved sequences $5^{\prime}$ to the GAA repeat motif and a highly conserved region about 60 bases $5^{\prime}$ to the start codon.

\section{DISCUSSION}

This study has identified and characterized a gene family in M. imitans that is homologous to lipoprotein gene families in $M$. gallisepticum (the pMGA gene family) and $M$. synoviae (the vlhA gene family). It seems appropriate that the three families be recognized as homologous by referring to them all as vilh $A$ gene families.

The pMGA genes of $M$. gallisepticum exhibit varying levels of DNA identity (40-98\%) and the coding regions share several structural features including a 25 -aminoacid leader sequence and signal peptidase II consensus cleavage sequence (Markham et al., 1993, 1994; Baseggio et al., 1996). The family members are predominantly organized as tandem repeats with an intergenic region of $350 \mathrm{bp}$. A consistent feature of the intergenic region is a GAA trinucleotide repeat region immediately preceding the promoter which has recently been shown to control transcription of these genes (Glew et al., 1998). The two genes characterized in $M$. 
(GAA) motif

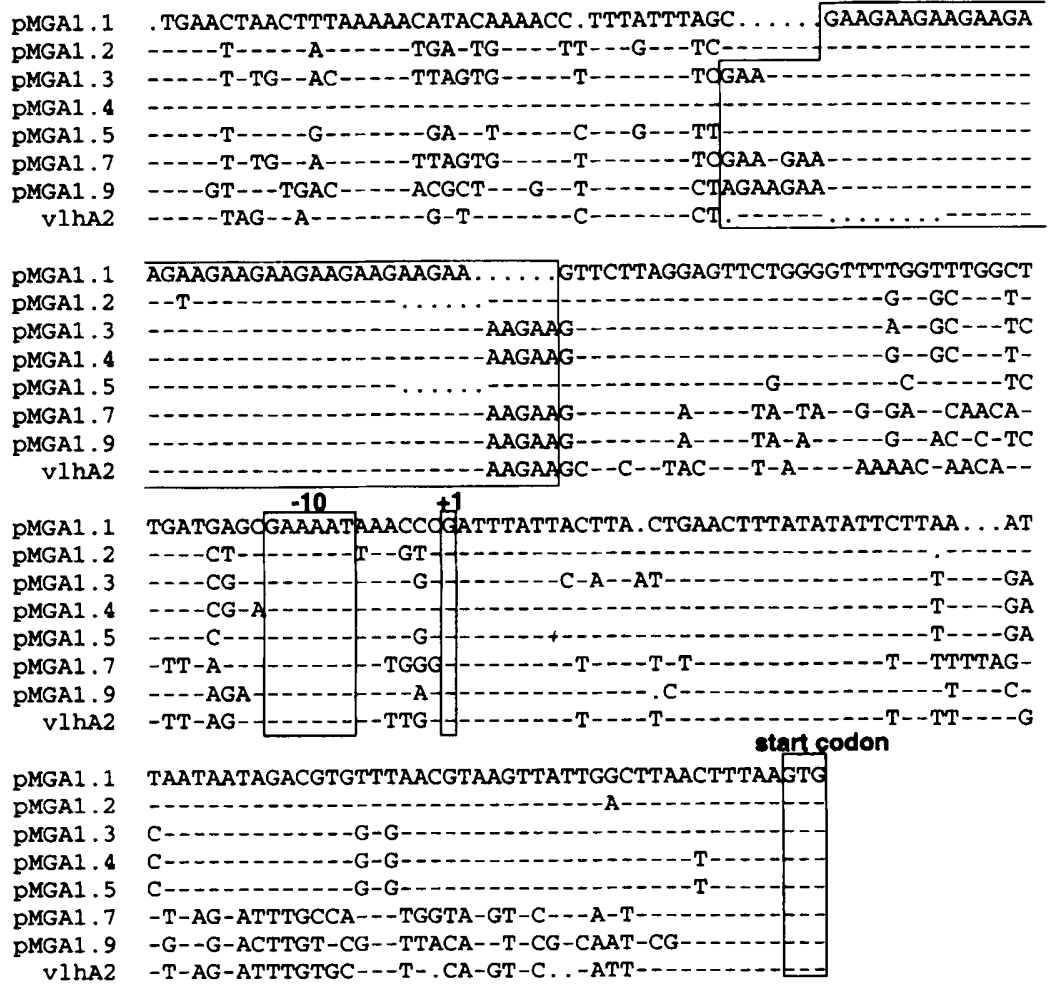

Fig. 5. Alignment of part of the 5 ' noncoding region of PMGA genes of $M$. gallisepticum and the vIhA2 gene of $M$. imitans. Gaps (shown as dots) were introduced within the sequence to maximize identity, dashes indicate bases conserved in all eight sequences and bases are shown if different from the consensus. Conserved regions are apparent either side of the GAA repeat region known to be responsible for control of transcription in the pMGA genes. The predicted -10 region is indicated together with the transcriptional start site $(+1)$ and start codon. imitans possessed a typical signal peptidase II cleavage sequence, a proline-rich imperfect repeat region at the amino-terminus of the mature predicted lipoprotein and several other regions of high sequence similarity which coincided with the most conserved regions of the pMGA genes. In addition one of the genes was found to be part of a gene family in $M$. imitans, the distribution of which had a close concordance with the distribution of GAA repeat sequences in the $M$. imitans genome. The GAA repeat region was located a similar distance $3^{\prime}$ to the end of coding sequence of the gene, compared to its location in pMGA genes, suggesting that the $M$. imitans gene family was also organized as tandem repeats, and that it was also likely to be regulated in a similar manner to the pMGA family. With up to $42 \mathrm{kbp}$ of genomic DNA hybridizing to the probe for the $M$. imitans gene, there may be up to 19 family members, assuming the gene length is $2 \cdot 2 \mathrm{kbp}$, as seen in the genes characterized in this study. It should be recognized that this is likely to be an overestimate of the extent of the family as it assumes that all hybridizing fragments are entirely composed of full-length copies of members of the family.

In Southern blot analysis the cloned $2 \cdot 1 \mathrm{kbp}$ fragment of $M$. imitans bound most strongly to a number of $M$. imitans and M. gallisepticum genomic DNA fragments and a single $1.8 \mathrm{kbp}$ EcoRI fragment of $M$. iowae. The pMGA1.2 DNA probe also bound the $1.8 \mathrm{kbp}$ EcoRI fragment of $M$. iowae, suggesting DNA sequences in common with both DNA probes. Faint reactivity was also observed between the $2 \cdot 1 \mathrm{kbp}$ probe and $M$. genitalium DNA, but a search of the $M$. genitalium genomic database suggested that this was associated with a limited GAA trinucleotide repeat region, not with homologous coding sequences.

Homologues of the $v$ lh $A$ families were not detected in other members of the pneumoniae phylogenetic group. However, it should be noted that the nucleic acid identity between pMGA genes and the $M$. imitans genes was between $49.7 \%$ and $60.2 \%$ and, as $M$. imitans and M. gallisepticum are much more closely related to each other than any other Mycoplasma species, homologues in other species may be difficult to identify using the methods applied in this study unless they were also associated with the characteristic GAA trinucleotide repeat.

Searches of the $M$. pneumoniae and $M$. genitalium databases with either the complete peptide sequences or consensus sequences or shorter conserved regions of pMGA genes and the $M$. imitans homologue failed to identify homologous genes. There are no GAA trinucleotide repeat regions in either genome which are located near predicted lipoprotein genes. While these findings suggest the absence of pMGA homologues in M. pneumoniae and M. genitalium, it is notable that the $M$. pneumoniae genome contains six lipoprotein gene families, none of which have identifiable homologues in any other bacterial species, and most members of these families are, like the pMGA genes, organized as tandem repeats. Further examination of the structure and function of these families may reveal homologies that are not apparent at the level of primary sequence. 
Rabbit immune sera raised to pMGA1.1 reacted with a $35 \mathrm{kDa}$ protein of $M$. imitans, which is smaller than the predicted size of the protein encoded by the ORF characterized in this study. This could be due to another wlh $A$ gene family member encoding a smaller product or possibly result from post-translational cleavage of the gene product. The product of $v$ lhA in $M$. synoviae is usually completely cleaved into an amino-terminal lipoprotein and a carboxyl-terminal haemagglutinin, and post-translational cleavage has been observed for one of the pMGA gene products in M. gallisepticum, although in this case some of the product remains uncleaved (Noormohammadi et al., 1997, 1998; Markham et al., 1998). Further studies will need to be conducted to determine if either of these propositions is correct.

Areas of conservation of the $5^{\prime}$ non-coding sequence of these genes, both within and between species, may provide further information about factors involved in the control of transcription and translation, both areas poorly understood in mycoplasmas. The high level of conservation of the GAAAAT motif 10 bases $5^{\prime}$ to the transcriptional start point suggests that this represents the -10 box, although the best consensus with E. coli promoters would be several bases $3^{\prime}$ to this. The other conserved regions could be hypothesized to play regulatory roles in either transcription or translation. Most importantly conservation $5^{\prime}$ to the GAA repeat motif known to control transcription lends support to the hypothesis that the length of this motif controls transcription by providing optimal spacing between RNA polymerase and a factor binding $5^{\prime}$ to the repeat motif (Glew et al., 1998). Experimental approaches to investigation of mycoplasma promoters are limited at present, and such observations provide a better focus for future studies of transcriptional control.

The $v l h A$ gene from $M$. synoviae encodes a surfaceexposed lipoprotein that shares $41 \%$ amino acid sequence similarity and $24 \%$ amino acid identity with VlhA1, indicating that VlhA1 is more closely related to M. gallisepticum pMGA1.1 and related sequences. It has been suggested that the gene families shared by $M$. synoviae and $M$. gallisepticum may have arisen by horizontal gene transfer, as pMGA gene homologues could not be identified in $M$. pneumoniae or $M$. genitalium, both of which are phylogenetically closer to $M$. gallisepticum than $M$. synoviae (Noormohammadi et al., 1998). Since M. gallisepticum, M. synoviae and M. imitans infect gallinaceous species, the observation that the same gene family occurs in each of these avian mycoplasmas but not in phylogenetically related human mycoplasmas strengthens the speculation that this family has been transferred horizontally between mycoplasmas sharing avian hosts. Curiously, the $v$ lh $A$ family of M. synoviae is not associated with GAA trinucleotide repeats, suggesting that, if the gene family originated from $M$. synoviae, the transfer preceded the divergence of M. gallisepticum and M. imitans, and that the coding regions and the promoter regions of the gene family have independent origins.

\section{ACKNOWLEDGEMENTS}

The authors wish to thank Associate Professor I. D. Walker for his helpful comments in the preparation of this manuscript. This research was funded by grants from the Australian Research Council and Bioproperties (Australia) Pty Ltd.

\section{REFERENCES}

Abdul, W. O., Ross, G. \& Bradbury, J. M. (1996). Pathogenicity and cytadherence of Mycoplasma imitans in chicken and duck embryo tracheal organ cultures. Infect Immun 64, 563-568.

Altschul, S. F., Gish, W., Miller, W. \& Myers, E. W. (1990). Basic local alignment search tool. $J$ Mol Biol 215, 403-410.

Baseggio, N., Glew, M. D., Markham, P. F., Whithear, K. G. \& Browning, G. F. (1996). Size and genomic location of the pMGA multigene family of Mycoplasma gallisepticum. Microbiology 142, 1429-1435.

Behbahani, N., Blanchard, A., Cassell, G. H. \& Montagnier, L. (1993). Phylogenetic analysis of Mycoplasma penetrans, isolated from HIV-infected patients. FEMS Microbiol Lett 109, 63-66.

Boyle, J. S. \& Morrow, C. J. (1994). Phylogeny of avian mycoplasmas: implications for mollicute taxonomy. Int Org Mycoplasmol Lett 3, 589.

Boyle, J. S., Good, R. T. \& Morrow, C. J. (1995). Detection of the turkey pathogens Mycoplasma meleagridis and $M$. iowae by amplification of genes coding for rRNA. J Clin Microbiol 33, 1335-1338.

Bradbury, J. M., Abdul, W. O., Yavari, C. A., Dupiellet, J. P. \& Bove, J. M. (1993). Mycoplasma imitans sp. nov. is related to Mycoplasma gallisepticum and found in birds. Int J Syst Bacteriol 43, 721-728.

Church, G. M. \& Gilbert, W. (1984). Genomic sequencing. Proc Natl Acad Sci USA 81, 1991-1995.

Dallo, S. F. \& Baseman, J. B. (1990). Cross-hybridization between the cytadhesin genes of Mycoplasma pneumoniae and Mycoplasma genitalium and genomic DNA of Mycoplasma gallisepticum. Microb Pathog 8, 371-375.

Ganapathy, K. \& Bradbury, J. M. (1998). Pathogenicity of Mycoplasma gallisepticum and Mycoplasma imitans in red-legged partridges (Alectoris rufa). Avian Pathol 27, 455-463.

Ganapathy, K., Jones, R. C. \& Bradbury, J. M. (1996). Pathogenicity of in vivo-passaged Mycoplasma imitans in turkey poults in single infection and in dual infection with infectious bronchitis virus. Avian Pathol 27, 80-89.

Glew, M. D., Baseggio, N., Markham, P. F., Browning, G. F. \& Walker, I. D. (1998). Expression of the pMGA genes of Mycoplasma gallisepticum is controlled by variation in the GAA trinucleotide repeat lengths within the $5^{\prime}$ noncoding regions. Infect Immun 66, 5833-5841.

Goh, M. S., Gorton, T. S., Forsyth, M. H., Troy, K. E. \& Geary, S. J. (1998). Molecular and biochemical analysis of a $105 \mathrm{kDa} M y c o-$ plasma gallisepticum cytadhesin (GapA). Microbiology 144, 2971-2978.

Inamine, J. M., Loechel, S., Collier, A. M., Barile, M. F. \& Hu, P.-C. (1989). Nucleotide sequence of the $\mathrm{MgPa}(m g p)$ operon of Mycoplasma genitalium and comparison to the P1 ( $m p p)$ operon of Mycoplasma pneumoniae. Gene 82, 259-267.

Keeler, C. L., Hnatow, L. L., Whetzel, P. L. \& Dohms, J. E. (1996). Cloning and characterization of a putative cytadhesin gene $(m g c 1)$ from Mycoplasma gallisepticum. Infect Immun 64, 1541-1547.

Kleven, S. H., Browning, G. F., Bulach, D. M., Ghiocas, E., Morrow, 
C. J. \& Whithear, K. G. (1988). Examination of Mycoplasma gallisepticum strains using restriction endonuclease DNA analysis and DNA-DNA hybridisation. Avian Pathol 17, 559-570.

Markham, P. F., Glew, M. D., Brandon, M. R., Walker, I. D. \& Whithear, K. G. (1992). Characterization of a major hemagglutinin protein from Mycoplasma gallisepticum. Infect Immun 60, 3885-3891.

Markham, P. F., Glew, M. D., Whithear, K. G. \& Walker, I. D. (1993). Molecular cloning of a member of the gene family that encodes pMGA, a hemagglutinin of Mycoplasma gallisepticum. Infect Immun 61, 903-909.

Markham, P. F., Glew, M. D., Sykes, J. E., Bowden, T. R., Pollocks, T. D., Browning, G. F., Whithear, K. G. \& Walker, I. D. (1994). The organisation of the multigene family which encodes the major cell surface protein, pMGA, of Mycoplasma gallisepticum. FEBS Lett 352, 347-352.

Markham, P. F., Glew, M. D., Browning, G. F., Whithear, K. G. \& Walker, I. D. (1998). The expression of two members of the pMGA gene family of Mycoplasma gallisepticum oscillates and is influenced by pMGA-specific antibodies. Infect Immun 66, 2845-2853.

Noormohammadi, A. H., Markham, P. F., Whithear, K. G., Walker, I. D., Gurevich, V. A., Ley, D. H. \& Browning, G. F. (1997).
Mycoplasma synoviae has two distinct phase-variable major membrane antigens, one of which is a putative hemagglutinin. Infect Immun 65, 2542-2547.

Noormohammadi, A. H., Markham, P. F., Duffy, M. F., Whithear, K. G. \& Browning, G. F. (1998). Multigene families encoding the major hemagglutinins in phylogenetically distinct mycoplasmas. Infect Immun 66, 3470-3475.

Su, C. J., Chavoya, J. \& Baseman, J. B. (1988). Regions of $\mathrm{Myco-}$ plasma pneumoniae cytadhesin P1 structural gene exist as multiple copies. Infect Immun 56, 3157-3161.

Tham, T. N., Ferris, S., Bahraoui, E., Canarelli, S., Montagnier, L. \& Blanchard, A. (1994). Molecular characterization of the P1-like adhesin gene from Mycoplasma pirum. J Bacteriol 176, 781-788.

Thompson, J. D., Higgins, D. G. \& Gibson, T. G. (1994). Clustal $\mathrm{W}$ : improving the sensitivity of progressive multiple sequence alignment through sequence weighting, position-specific gap penalties and weight matrix choice. Nucleic Acids Res 22, $4673-4680$.

Weisburg, W. G., Tully, J. G., Rose, D. L. \& 9 other authors (1989). A phylogenetic analysis of the mycoplasmas: basis for their classification. J Bacteriol 171, 6455-6467.

Received 17 February 1999; revised 26 April 1999; accepted 13 May 1999. 